Review

\title{
Survey of Pharmacological Activity and Pharmacokinetics of Selected $\beta$-Adrenergic Blockers in Regard to Their Stereochemistry
}

\author{
Ružena Čižmáriková, Ladislav Habala *, Jindra Valentová and Mário Markuliak \\ Department of Chemical Theory of Drugs, Faculty of Pharmacy, Comenius University Bratislava, \\ SK-832 32 Bratislava, Slovakia; cizmarikovaruz@gmail.com (R.Č.); valentova@fpharm.uniba.sk (J.V.); \\ markuliak@gmail.com (M.M.) \\ * Correspondence: habala@fpharm.uniba.sk
}

Received: 18 January 2019; Accepted: 8 February 2019; Published: 13 February 2019

check for updates

\begin{abstract}
The present survey concentrates on pharmacodynamics and pharmacokinetics of selected $\beta$-adrenergic blockers from the point of view of their stereochemistry. It could be shown that the activity in the arylaminoethanol and aryloxyaminopropanol group of $\beta$-blockers is higher in their (-)-enantiomers as compared with the (+)-enantiomers. The stereoisomers differ also in other types of bioactivity as well as in toxicity. The particular pharmacokinetic stages such as resorption, distribution, and metabolism are discussed in regard to their stereochemistry.
\end{abstract}

Keywords: beta-blockers; stereochemistry; pharmacodynamics; pharmacokinetics

\section{Introduction}

$\beta$-blockers have been used as drugs for more than 50 years in the therapy of several diseases of the cardiovascular system [1] as well as in other disorders connected with an increase in sympathetic tone, such as glaucoma [2,3], anxiety [4], thyrotoxicosis [5], osteoporosis [6], and migraine prophylaxis [7]. The study of this drug group is substantiated by high incidence rate of cardiovascular diseases [8], such as ischemic heart disease, hypertension [9-12], heart arrhythmia, hypertrophic cardiomyopathy [13], and heart failure [8,14], all of which have been brought into connection with $\beta$-adrenergic receptors. These disorders are among the main mortality causes and at present affect increasingly younger fractions of population.

The particular $\beta$-blockers differ in the extent of preferential binding to $\beta_{1}$-adrenergic receptors, that is, in their cardioselectivity, the extent of antagonist activity toward $\beta$-receptors, pharmacokinetic properties, and the presence or absence of intrinsic sympathomimetic activity (ISA). These properties further determine the differences in side effects and potential contraindications. $\beta$-blockers may be classified according to their pharmacodynamics, pharmacokinetics or duration of action [15]. They are usually categorized into following groups:

A. Cardioselective $\beta$-adrenolytics without ISA.

They affect mainly $\beta_{1}$-receptors, while $\beta_{2}$-receptors are blocked only at higher doses. The examples include atenolol, betaxolol, bisoprolol, esmolol, metoprolol, and nebivolol.

B. Cardioselective $\beta$-adrenolytics with ISA.

Because of their agonist activity they are sometimes called $\beta$-adrenolytics with vasodilatant effect. Typical members of this group are acebutolol and celiprolol. 
C. Non-selective $\beta$-adrenolytics without ISA.

They act on both subtypes $\left(\beta_{1}\right.$ and $\left.\beta_{2}\right)$ of $\beta$-adrenergic receptors. Metipranolol, nadolol, propranolol, sotanol, and timolol belong to this group.

D. Non-selective $\beta$-adrenolytics with ISA.

In addition to the blocking of $\beta$-receptors they also exert partial agonist activity. ISA causes minor reduction of bradycardia and cardiac output. Examples are bopindolol and pindolol.

E. $\beta$-adrenolytics blocking simultaneously $\alpha$ - and $\beta$-receptors.

Apart from $\beta$-receptors they act partly also on $\alpha$-receptors. Carvedilol and labetalol belong to this group.

F. Lipophilic $\beta$-adrenolytics.

They are better metabolized in the liver and exhibit improved resorption and penetration of the blood-brain barrier, thus lowering the incidence of sudden heart failure.

G. Hydrophilic $\beta$-adrenolytics.

These drugs do not penetrate the central nervous system (CNS). They are to a greater degree capable of binding to plasma proteins and are eliminated renally [16].

\section{Chirality of $\beta$-Blockers}

$\beta$-adrenergic blockers are among the first categories of drugs investigated for their chiral aspects. They contain one or several stereogenic centers in their structure and thus are able to rotate the plane of polarization of linearly polarized light either to the left $(-)$ or to the right $(+)$. In older literature we can also find the terms laevo (l) and dextro (d) to describe the direction of rotation of polarized light. The spatial arrangement of substituents around the stereogenic center, for example the so-called absolute configuration, can be described with the help of the Cahn-Ingold-Prelog (CIP) system $[17,18]$. According to their chemical structure these drugs can be classified as arylaminoethanols or aryloxyaminopropanols (Figure 1). In both groups the more active isomers pertaining to their $\beta$-adrenolytic activity are the (-)-isomers which can be attributed the $(R)$-configuration for the arylaminoethanol group and $(S)$ for the aryloxyaminopropanol group.
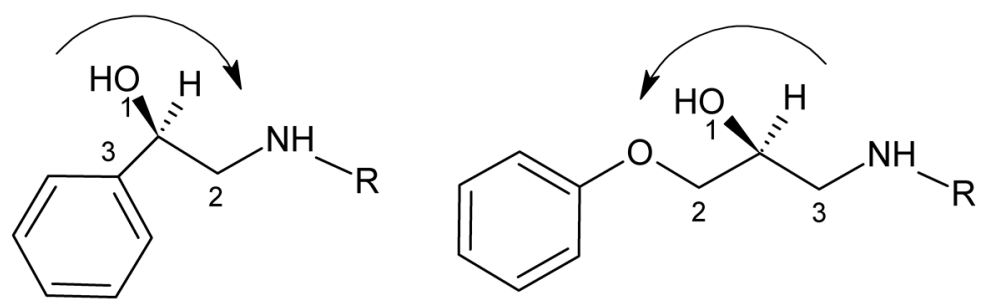

Figure 1. Structure and stereochemistry of arylaminoetanols (left) and aryloxyaminopropanols (right).

The understanding of the chiral aspects of $\beta$-blockers in connection with their pharmacodynamic and pharmacokinetic properties is essential for achieving the optimum therapeutic effect.

The differences in pharmacodynamic and pharmacokinetic properties of the optical antipodes are determined by their specific interactions with chiral biomolecules, such as proteins involved in the active membrane transport, blood plasma proteins, enzymes involved in metabolic processes, etc. A three-point model can be used for explanation of differences in the behavior of enantiomers regarding their interaction with the receptors. The more active stereoisomer forms three complementary binding interactions with the active site of the receptor while the less active stereoisomer is capable of 
forming only two binding interactions. The molecules of $\beta$-blockers generally utilize the aromatic ring, the amino and hydroxy groups to affect the binding to the receptor. To distinguish between the different pharmacological activities of the two enantiomers, Lehmann and Ariens [19-21] applied the designation eutomer to the desirable, more active enantiomer, whereas the designation distomer applies to the less favorable enantiomer (in terms of activity and/or toxicity). This classification is related to a specific kind of bioactivity, thus a distomer may be considered a eutomer in different type of pharmacological application.

In the therapeutic practice the $\beta$-blockers have mostly been used in the form of their racemates, with the exception of penbutolol, timolol, atenolol, and levobunolol which are used as pure enantiomers [22]. To evaluate the impact of stereochemistry on the bioactivity of $\beta$-blockers, new techniques for obtaining enatiomerically pure isomers of these drugs are under development, such as stereoselective synthesis, chromatographic methods of enantioseparation, and other techniques [23].

\subsection{Interaction of $\beta$-Blockers With the Receptor Protein}

The mechanism of activity of the particular enantiomers of $\beta$-blockers can be explained in terms of more effective binding of the more active stereoisomer to the receptor site under strictly defined stereochemical conditions. Crucial role in the binding to the receptor is played by specific functional groups present in the molecule of the blocker, in particular the amino and hydroxy groups, and substituted aromatic rings.

The $\beta$-receptor as a protein macromolecule consists of $388-477$ amino acids, forming seven transmembrane helices with three intracellular and three extracellular loops. The amino acid residues provide for specific interactions with the molecules of $\beta$-blockers. Molecular models of propranolol suggest that the protonized amino group and the hydroxy group form hydrogen bonds with Asp113. The naphthalene moiety participates in hydrophobic interactions with Try109, Phe289, and Val292. The propan-2-yl (isopropyl) group of propranolol also provides hydrophobic interactions with Ile112, Pro288, and Cys285. In pindolol and carazolol the NH group present in the heterocyclic moiety (indole, carbazole) forms hydrogen bonds with Ser204 and Ser207, providing an explanation for their added ISA activity [24].

\subsection{The Arylaminoethanol Group of $\beta$-Blockers}

$\beta$-blockers generally act as competitive agonists of catecholamines and block the excessive activity of the sympathomimetic system. The chemical structure of $\beta$-blockers belonging to this group is derived from the sympathomimetic isoprenaline. The first synthesized $\beta$-blockers were structural analogues of this compound, starting with dichloroisoprenaline [25]. Further derivatives include nifenalol [26,27] and pronethalol, applied temporarily in clinical practice [28].

\subsubsection{Pronethalol}

The $(R)-(-)$-enantiomer of pronethalol was 49 times more active than the (S)-(+)-form [29]. Antidysrhythmic activity in oubain- and adrenalin-induced arrhythmias was the same with racemic pronethalol and its $(S)-(+)$-isomer, while the $(R)-(-)$-isomer exhibited only low activity [30]. This indicates that the effect is non-specific.

Although pronethalol exerted marked pharmacodynamic effects, its clinical use was abandoned due to its carcinogenicity detected in mice [31]. In more recent literature, pure enantiomers of these substances have been prepared by stereoselective synthesis or preparative enantioseparation and studied separately $[32,33]$. From the arylaminoethanol group of $\beta$-blockers, sotalol and labetalol are still in clinical use (Figure 2). 
<smiles>CC(C)NCC(O)c1ccc(NS(C)(=O)=O)cc1</smiles>

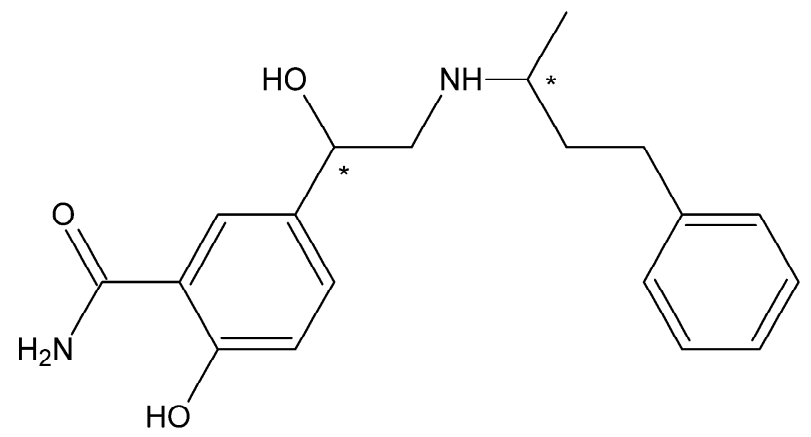

Figure 2. Structural formulas of sotalol (left) and labetalol (right).

\subsubsection{Sotalol}

This antidysrhythmic of II. and III. class in the Vaughan-Williams classification is used to treat chamber arrhythmias. Its $(R)-(-)$-enantiomer is $14-50$ times more efficient at blocking $\beta$-receptors than its racemic form, while its $(S)-(+)$-enantiomer is practically inactive. The antidysrhythmic activity based on the blockage of $\mathrm{K}$ channels was equal in both enantiomers, justifying the utilization of the $(S)-(+)$-enantiomer in this indication. Application of this isomer in patients with disruption of ventricular function and subsequent infarction has to be abandoned due to increased mortality in patients receiving $(S)-(+)$-sotalol [34-36].

\subsubsection{Labetalol}

From the chemical point of view the substance is related to salicylamide, bearing in the basic part of the aminoethanol moiety 4-phenylbutan-2-yl group instead of branched groups such as propan-2-yl (isopropyl) or 2-methylpropan-2-yl (tert-butyl). Labetalol is thus capable of simultaneous blockage of $\alpha$ and $\beta$-receptors. As a result of this combined adrenolytic activity, labetalol is used as a mixture of four stereoisomers for the indication of hypertension. Recent investigations substantiated the suitability of this drug also in controlling hypertensive crisis in patients with hypertensive disorders of pregnancy (HDP), similarly to hydralazine [37].

In regard to the stereochemistry of the isomers of labetalol, the (SR)-isomer exerts $\alpha$-lytic activity, whereas the $(R R)$-form blocks only $\beta$-receptors [38]. The (SS)- and $(R S)$-isomers are inactive. Despite exhibiting higher ISA activity in clinical tests, the usage of the pure (RR)-isomer (dilevalol) had to be discontinued due to occurrence of hepatitis during the therapy. Since in the racemic form of the drug no hepatotoxicity was encountered, the question remains whether the other enantiomer shows hepatoprotective properties. This clearly indicates that the employment of pure enantiomeric form of a drug is not always of advantage.

\subsubsection{Bufuranol}

In the group of heterocyclic analogues marked activity was exhibited by bufuranol, 2-(2-methylpropan-2-ylamino)-1-(7-ethyl-1-benzofuran-2-yl)ethanol, a non-selective $\beta$-blocker with intrinsic sympathomimetic effects. Higher activity was found in its $(R)-(-)$-isomer [39-42].

\subsection{The Aryloxyaminopropanol Group of $\beta$-Blockers}

In the course of further derivatization, remarkable results were achieved by introducing an oxymethylene bridge between the aromatic part and the aminoethanol side chain. These derivatives surpass the corresponding arylaminoethanol analogues by a factor of 10 . Chiral aspects of this category have been studied more extensively than in the previous group of $\beta$-blockers. 


\subsubsection{Monocyclic Compounds}

Substitution of the basic structure with various electron-donating or electron-withdrawing groups leads to quantitative as well as qualitative variations in the activity of $\beta$-blockers. It could be shown that 2-(ortho) and 3-(meta) substitution of the aromatic ring increases their activity, whereas para-substitution shifts the equilibrium towards higher inhibition of cardiovascular receptors.

Among the 3-(meta)substituted derivatives the most studied $\beta$-blocker was toliprolol, a derivative exhibiting high $\beta$-adrenolytic activity and only minor cardiodepressive effect. The derivatization in the basic part of the molecule yields bevantolol with increased cardioselectivity.

In the group of 2-(ortho)-substituted derivatives, allyl and allyloxy analogues were investigated in more detail [43-48]. The (S)-(-)-enantiomer of the $\beta$-blocker oxprenolol is 35 -times more active than its $(R)-(+)$-enantiomer while in alprenolol the ratio is 100 in favor of the (S)-(-)-isomer.

The (S)-(-)-form of moprolol, 1-(2-methoxyphenoxy)-3-(propan-2-ylamino)propan-2-ol, a $\beta$-blocker containing methoxyl group, showed marked $\beta$-blocking effect in experiments on Purkinje fibers while the $(R)-(+)$-isomer was inactive [49].

Penbutolol (Figure 3) was the first $\beta$-blocker applied in the clinic as enantiomerically pure (S)-(-)-isomer. It was 200 times more active in both in vitro and in vivo experiments than its $(R)-(+)$-enantiomer and five times more active than propranolol used as standard. Unlike the $(R)-(+)$-enantiomer, the laevo-rotating isomer exhibits intrinsic sympathomimetic activity (ISA) and antiarrhythmic effect based on the blockage of $\beta$-adrenergic receptors [50].

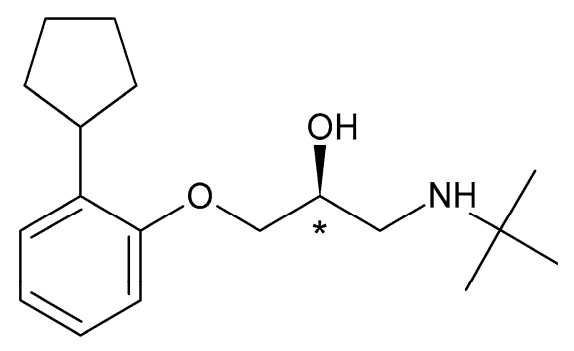

Figure 3. Chemical structure of the (S)-(-)-isomer of penbutolol.

In the group of 4-(para-) substituted derivatives, metoprolol (methoxyethoxy group in position 4) found its way into therapeutic practice. The $(S)-(-)$-enantiomer of metoprolol exhibits preference towards $\beta_{1}$-adrenergic receptors while the $(R)$ - $(+)$-isomer as a non-selective $\beta$-blocker blocks equally $\beta_{1}$ and $\beta_{2}$ receptors [51,52].

\section{Betaxolol}

The (S)-(-)-form of betaxolol (levobetaxolol), a $\beta$-blocker devoid of intrinsic sympathomimetic activity with a cyclopropoxyethyl group (Figure 4), was found to be efficient in reducing intraocular pressure in patients affected with primary open-angle glaucoma and ocular hypertension. Marked differences in the activity of different enantiomers were encountered also in atenolol, a carbamoylmethyl derivative used in the treatment of angina pectoris and in glaucoma [53-55].<smiles>CC(C)NC[C@H](O)COc1ccc(CCOCC2CC2)cc1</smiles>

Figure 4. Chemical structure of betaxolol. 
Esmolol

This $\beta$-blocker (Figure 5) with easily hydrolysable ester moiety is a cardioselective ultrashort-acting $\beta_{1}$-selective antagonist. The ester group present in the structure of esmolol undergoes rapid hydrolysis in blood, leading to quick onset of the pharmacological effect as well as its rapid abatement. Its metabolite, 3-\{4-[2-hydroxy-3-(propan-2-ylamino)propoxy]phenyl\}propionic acid, has 400 times lower activity towards $\beta_{1}$-receptors than esmolol [56]. Due to its rapid activity onset it is applied as racemate in life-threatening situations such as sudden cardiac arrest. It finds further use in the therapy of ventricular and supraventricular arrhythmias [57,58]. The results of a study [59] suggest that the antiarrhythmic activity is connected to the inhibitory effect of sodium ions. It could be shown that the blocking activity resides with the $(S)-(-)$-enantiomer, whereas the $(R)-(+)$-isomer was found to be inactive. In studies with radioactive tracers esmolol exhibited 34 times higher activity towards $\beta_{1}$-receptors in comparison to $\beta_{2}$-receptors.

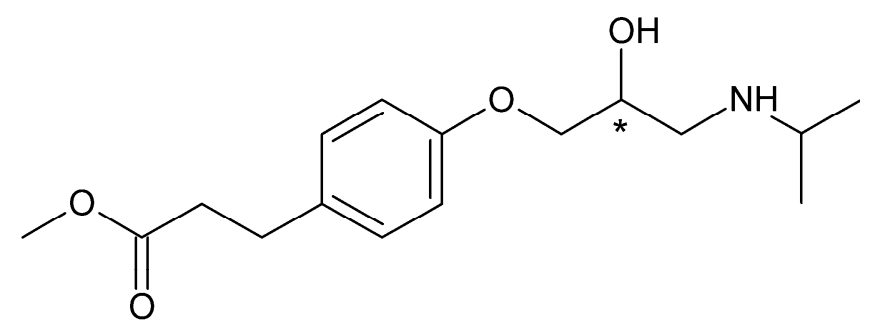

Figure 5. Chemical structure of esmolol.

In the work [60] stereoselective hydrolysis of esmolol in vitro and in vivo was studied. Dog and rat blood esterases hydrolyzed the (-)-enantiomer of esmolol faster than the (+)-enantiomer while rhesus monkey, rabbit, and guinea pig blood esterases hydrolyzed the (+)-enantiomer more rapidly. Human blood esterases did not demonstrate stereoselectivity. Dog liver esterases also showed stereoselectivity towards the (-)-enantiomer but dog skeletal muscle esterases did not.

In the study [61] the stereoselective pharmacokinetics of enantiomers was compared after a single intravenous administration of ${ }^{14} \mathrm{C}$-esmolol hydrochloride to dogs. The findings suggest that pharmacokinetics of the particular enantiomers differs slightly in dog, whereas there are no stereoselective differences in human blood kinetics.

\subsubsection{Monocyclic Derivatives with Several Substituents}

In an effort to combine positive effects of substitution in 2-(ortho) and 4-(para) positions, a number of new $\beta$-blockers with a high index of pharmacological activity were developed. Different activities of the respective enantiomers were observed in structurally related drugs acebutolol and celiprolol.

Celiprolol, 3-\{3-acetyl-4-[3-(2-methylpropan-2-ylamino)-2-hydroxypropoxy]phenyl\}-1, 1-diethylurea, a third-generation $\beta$-blocker, exhibits intrinsic vasodilatory activity based on the stimulation of $\beta_{2}$-adrenergic receptors. Much higher antiisoprenaline activity was observed in guinea pigs using $(S)-(-)$-isomer as compared to $(R)-(+)$-isomer and the racemic mixture [62].

\subsubsection{Bicyclic Derivatives}

Several reports suggest the feasibility of the attachment of another ring to the benzene ring without considerably affecting the $\beta$-adrenolytic activity.

\section{Propranolol}

The (S)-(-)-isomer of propranolol, a well-established $\beta$-blocker (Figure 6), is 60 to 100 times more active than the $(R)-(+)$-form [63-65]. The importance of suitable steric configuration for the $\beta$-adrenolytic activity is corroborated also by the experimental finding that $N$-(3-naphthyloxypropyl)- $N$ propan-2-ylamine containing no stereogenic centers in its molecule exerts approximately the same 
activity in isoprenaline-induced tachycardia as the less active isomer of propranolol. Interestingly, different results could be observed depending on the type of arrhythmia. The antiarhythmic anti-oubain activities of racemic propranolol and its (+)-isomer were equal, whereas the (-)-form had only weak effects. In halothane/adrenalin-induced arrhythmias the antidisrhythmic effect of racemic propranolol was the same as that of its (-)-isomer, whereas its (+)-isomer was nearly 10 times less active. These results support the view that in the former case potentiating of the antidisrhythmic effects was connected to the membrane-stabilizing properties of the $(R)-(+)$-isomer while in the latter case the activity might possibly be based on the inhibition of adrenergic hyperactivity.

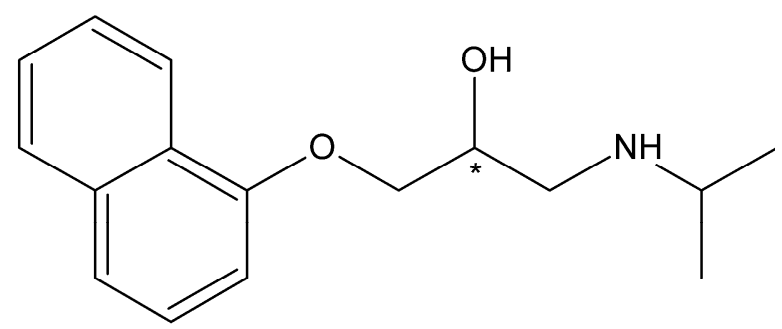

Figure 6. The structure of propranolol.

Recently, it was shown that racemic propranolol exhibits higher toxicity in rat than both its pure enantiomers. This increase in toxicity can be at least partially based on pharmacokinetic interactions [66,67].

Daphnia magna and Pimephales promelas were employed as model organisms for aquatic invertebrates and vertebrates, respectively, in order to assess the toxicity of the respective enantiomers of propranolol [68]. The enantiospecific effects of propranolol on Daphnia magna heart rate were determined as well. High-performance liquid chromatography - mass spectrometry (HPLC/MS) was used to establish propranolol treatment levels. In all cases the treatment provided similar acute responses. In terms of chronic toxicity, (S)-propranolol was more toxic than its $(R)$-isomer in Pimephales promelas but not in Daphnia magna This might be due to lack of $\beta$-type receptors in cladocerans. In regard to acute responses, no enantiospecific activity on daphnid heart rate was encountered.

Nadolol

Nadolol incorporates in its molecule tetrahydronaphthalene scaffold with three stereogenic centers (Figure 7). It contains two hydroxyl groups in (Z)-configuration, their absolute configurations being $(2 R)$ and ( $3 S)$, respectively, and a hydroxyl group in the side-chain in ('2RS)-configuration. It is applied as a mixture of four stereoisomers (two diastereomers each forming a pair of enantiomers). One of the racemates contains the most active isomer (RSR) along with its corresponding enantiomer $(S R S)$. As regards the clinical application of nadolol, the most advantageous option seems to be the application of the enantiomerically pure (RSR) isomer [69-71].<smiles>CC(C)(C)NCC(O)COc1cccc2c1CC(O)=C(O)C2</smiles>

Figure 7. Chemical structure of nadolol. 
Bunolol

This non-selective $\beta$-blocker without intrinsic sympathomimetic activity and with mild local anesthetic effect is three times more active than propranolol [72,73]. It is used in the clinic in its enantiomerically pure form as levobunolol, in the therapy of hypertension, angina pectoris and especially in glaucoma [74]. The structure of bunolol is depicted in Figure 8.

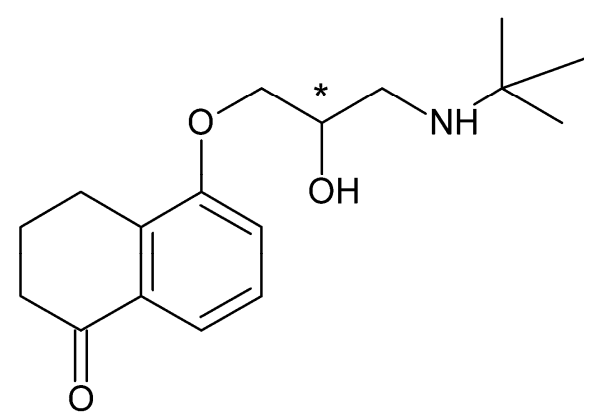

Figure 8. Chemical structure of bunolol.

\subsubsection{Heterocyclic Derivatives}

The substitution of the carbocyclic aromate for a heterocycle does not lead to significant changes in $\beta$-adrenolytic activity.

\section{Timolol}

Timolol (Figure 9) is a heterocyclic $\beta$-blocker applied in the clinic as pure (S)-isomer, which is approximately 54 times more active than its $(R)$-antipode [75,76]. The utilization of the $(S)-(-)$-enantiomer can lead to undesirable effects, such as bradycardia, hypotension, bronchospasms, even to exitus. Thus, the use of the less active and at the same time less toxic $(R)-(+)$-isomer for this indication might be of advantage.

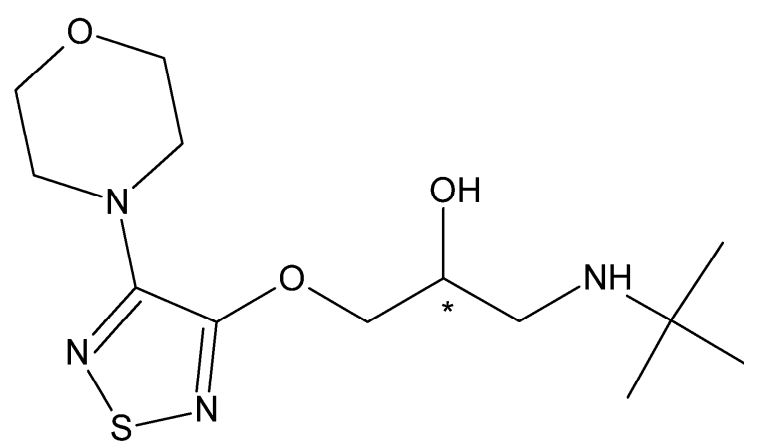

Figure 9. Chemical structure of timolol.

\section{Carvedilol}

Carvedilol (Figure 10) is a non-selective $\beta$-blocker with additional $\alpha_{1}$-blocking activity and antioxidative effect. It contains carbazole core in the lipophilic part of the molecule and 2-ethoxyphenylethoxy moiety connected to the basic nitrogen in the hydrophilic part. It finds application in its racemic form in the therapy of congestive heart failure as an antihypertensive. Its respective enantiomers exhibit different but complementary activities. While the $(S)$-enantiomer blocks $\alpha$ - and $\beta$-adrenergic receptors, the $(R)$-form is a pure $\alpha_{1}$-antagonist. The racemate does not markedly lower the heart rate, whereas the $(R)$-carvedilol causes even its slight increase [77]. 


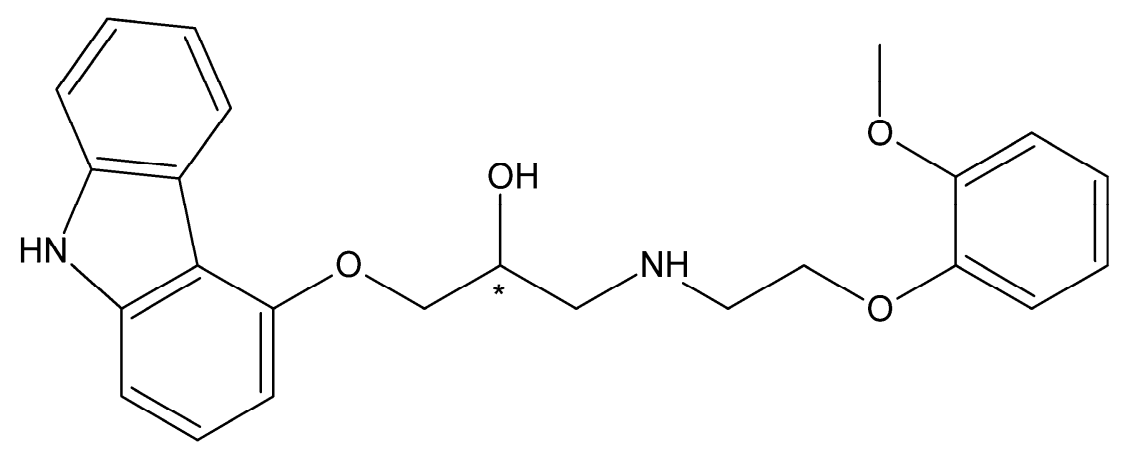

Figure 10. Chemical structure of carvedilol.

Nebivolol

The structure of nebivolol differs considerably from those of the other $\beta$-blockers (Figure 11). The aromatic ring is not attached to the aminopropanol moiety through etheric oxygen but the oxygen atom is incorporated in the fluorochromane scaffold linked to bisaminoethanol. The molecule of nebivolol contains four stereogenic centers, which should theoretically lead to 16 stereoisomers. In reality, the number of stereoisomers is smaller (10) due to the symmetry of the molecule [78].<smiles>OC(CNC[C@H](O)C1CCc2cc(F)ccc2O1)=C1CCc2cc(F)ccc2O1</smiles>

Figure 11. The structure of nebivolol.

(+)-Nebivolol with (SRRR) configuration exhibits $\beta_{1}$-blocking activity. (-)-Nebivolol (RSSS) has vasodilatory effect based on the activation of endothelial NO synthase. Racemic $( \pm)$-nebivolol as well as its (+)-enantiomer have 200 times higher activity towards $\beta_{1}$-receptors than (-)-nebivolol, leading to selective $\beta$-blockage [79-82].

\section{Pharmacokinetics of Chiral $\beta$-Blockers}

In addition to their pharmacological properties, many $\beta$-blockers differ also in their pharmacokinetics [83]. In a number of cases, the influence of chirality of particular $\beta$-blockers on their pharmacokinetic behavior (resorption, distribution, and metabolism) has been investigated.

\subsection{Resorption}

$\beta$-blockers are resorbed from gastrointestinal tract by passive diffusion, which is not stereospecific. Some $\beta$-blockers, however, undergo intestinal secretion, a process possibly showing some stereoselectivity (e.g., talinolol). Lipophilic $\beta$-blockers (pindolol, timolol, metoprolol, oxprenolol, alprenolol, and propranolol) are subject to rapid even if relatively non-uniform resorption. Their concentrations in blood plasma show 10- to 20-fold differences in different patients given the same dose. Of course, these differences can be at least partly accounted for also by the first-pass effect. Hydrophilic $\beta$-blockers (sotalol, atenolol, nadolol, and practolol) are resorbed by the gastrointestinal tract only incompletely $[84,85]$.

\subsection{Distribution}

$\beta$-blockers bind to albumins of blood plasma and to $\alpha_{1}$-glycoprotein. Since proteins are generally chiral, as a result of the chirality of their building blocks, the binding of enantiomerically pure 
$\beta$-blockers should be stereospecific. Acebutolol, pindolol, and sotalol show relatively high level of free fraction in plasma. Propranolol was found to exhibit stereospecific binding to proteins as well. It could be established that its binding to human serum albumin differs from the binding to $\alpha_{1}$-glycoprotein (it is higher in the latter case). Age and gender of the test persons had no influence on binding to plasma proteins $[86,87]$.

The tissue distribution of propranolol and pindolol was investigated in animal experiment. Dependence of the stereospecific binding to plasma proteins on concentrations of the enantiomers of $\beta$-blockers in various tissues could be established. Resorption by tissues seems to be stereospecifically independent. Stereospecificity in the distribution of the respective pharmacon by erythrocytes could be postulated as well $[88,89]$. Hydrophilic (atenolol) as well as lipophilic (propranolol) $\beta$-blockers are stored and excreted from the endings of the sympathicus. Lipophilic $\beta$-blockers are resorbed by passive diffusion, which is not stereospecific [90].

\subsection{Metabolism}

Different enantiomers undergo different transformations in the course of metabolic processes. This can result in the accumulation of the inactive enantiomer, rapid elimination of the active enantiomer, or vice versa. The respective enantiomers of the same $\beta$-blockers also activate or inhibit stereoselectively enzymes of the cytochrome P-450 complex. At present, we recognize several isoforms of this cytochrome (e.g., CYP2D6, CYP3A4), which are susceptible to activation or inhibition. $\beta$-blockers are degraded by these isozymes and their metabolism can be affected by other substances [91,92].

Propranolol and other lipophilic $\beta$-blockers are metabolized in the liver. Hydrophilic $\beta$-blockers (atenolol and sotalol) are excreted via kidneys, in unchanged form or as active metabolites. This is beneficial especially in patients with impaired liver function.

$\beta$-blockers with equilibrium clearance (e.g., bisoprolol and pindolol) have a low first-pass metabolism, high bioavailability following oral uptake, and are excreted evenly by kidney as well as by liver [93].

Propranolol is metabolized via three main pathways: glucuronidation, hydroxylation of the aromatic ring, and oxidation of the side chain. Upon investigation, eleven metabolites could be identified; approximately $1 \%$ was eliminated unchanged. Structures of selected metabolites are given in Figure 12. Hydroxylation of the naphthalene ring in $(R)-(+)$-propranolol proceeds stereospecifically in positions 4 and 5 . The hydroxy derivative of (S)-(-)-propranolol preferentially forms conjugates with glucuronic acid while its optical antipode yields sulfates. Oxidative degradation of the side-chain leads to carboxylic acids (from 1-naphthyloxybutanoic acid to naphthyloxyacetic acid)-a characteristic degradation pathway found in many other aryloxyaminopropanols [94,95].

Metabolism of propranolol is influenced by genetic polymorphism of the isozymes of cytochrome P-450, especially CYP1A (mephenytoin hydroxylation) and CYP2D6 (debrisoquine hydroxylation). In vitro and in vivo studies revealed that $N$-desalkylation of propranolol is catabolyzed by cytochrome subgroup CYP1A and hydroxylation of the naphthalene ring by cytochrome CYP2D6 subgroup. Both metabolic pathways for propranolol are insufficient in slow metabolizers of debrisoquine and mephenytoin (affecting $0.4 \%$ of the population). At low concentrations of the substrate the $(R)-(+)$-enantiomer is metabolized preferentially. The $(S)-(-)$-isomer of propranolol is metabolized first at higher concentrations. This is due to saturation of first-pass metabolism, especially for $(R)-(+)$-propranolol. Further investigations are needed to clarify the consequences of this fact for the clinic [95].

As suggested by several studies, some drugs suppress the metabolism of propranolol, in particular of its $(R)-(+)$-enantiomer. Calcium channel blockers (nicardipine, verapamil, diltiazem) suppress the first-pass metabolism of both enantiomers of propranolol, with a preference for the $(R)-(+)$-isomer. In a similar way, cimetidine (an antagonist of H2-receptors) reduces clearance of $(R)-(+)$-propranolol [96]. Quinidine, a selective inhibitor of CYP2D6, diminishes hydroxylation of the aromatic part of propranolol, especially of its $(R)-(+)$-isomer $[97,98]$. 
<smiles>CC(C)NCC(O)COc1cccc2c(O)cccc12</smiles><smiles>CC(C)NCC(COc1cccc2ccccc12)OS(=O)(=O)O</smiles>

Figure 12. Chemical structures of selected metabolites of propranolol.

Clearance of propranolol was found to be $63 \%$ higher in men than in women. The reason for this is the rapid metabolizing of the side-chain and glucuronidation during the first pass through the liver in men [99].

Metoprolol is also metabolized in the liver by cytochrome CYP2D6, involving oxidation and $\alpha$-hydroxylation of benzyl $(10 \%)$. This pathway is stereospecific for $(S)-(-)$-metoprolol. $O$-demethylation and oxidation to carboxylic acids represent the main metabolic routes, particularly for $(R)-(+)$-metoprolol $(65 \%)$, and are inhibited by verapamil. The third metabolic pathway involves $N$-desalkylation $(<10 \%)[100]$.

$\alpha$-Hydroxymetoprolol possesses only one tenth of the activity of metoprolol. However, the hydroxylation of benzyl leads to formation of a new stereogenic center. Studies in vitro and in vivo revealed preferred formation of the (1'R)-configuration [101].

Due to genetic polymorphism, the concentration of racemic propranolol after the administration was 6 times higher in slow metabolizers of debrisoquine as compared to normal metabolizers. Moreover, drugs inhibiting cytochrome CYP2D6, such as chloroquine and halofantrine (antimalarials), propafenone (an antidysrhythmic), as well as inhibitors of selective reuptake of serotonin, decrease the clearance of metoprolol. Investigations in healthy persons showed that co-administration of metoprolol and paroxetin leads to marked increase in bioavailability, plasma levels, and biological half-life of metoprolol. At the same time, higher concentration of $(R)$-metoprolol was observed. Cimetidine markedly improves the bioavailability of metoprolol, approx. one third of this increase being attributable to the $(S)$-enantiomer and the remainder to the $(R)$-isomer. Thus, it should not 
come as a surprise that it is difficult to observe this interaction in the clinic. The antituberculotic rifampicin (an activator of microsomal enzymes), on the other hand, lowers the bioavailability of metoprolol [102-104].

Peřinová et al. [105] reported a method for determination of metoprolol and $\alpha$-hydroxymetoprolol in human serum. The method is aimed at the evaluation of the enzyme phenotype of CYP2D6 with metoprolol as substrate. A survey of different methods for determination of metoprolol along with its metabolite $\alpha$-hydroxymetoprolol is presented in the report. The respective stereoisomers of metoprolol were determined in plasma by stereoselective HPLC combined with tandem mass spectrometry. Chiral column Chirobiotic T with methanol/acetic acid/ammonia 100/0.15/0.15 v/v/v as the mobile phase was employed. Ion trap in combination with ESI ion source in positive ion mode was used for MS detection. The structures of selected metabolites of metoprolol are depicted in Figure 13.<smiles>COCC(O)c1ccc(OCC(O)CNC(C)C)cc1</smiles>

Figure 13. Chemical structures of some metabolites of metoprolol.

Carvedilol is metabolized mainly by CYP2D6, a small part also by cytochrome CYP3A4. Thus, its biological half-life will be prolonged in patients with impaired liver function. (S)-carvedilol is metabolized by CYP2D6 and its $(R)$-antipode by CYP2D9 [106]. In slow metabolizers of carvedilol only the metabolism of the $(R)-(+)$-isomer is inhibited, leading to marked increase in $\alpha_{1}$-adrenolytic activity, while the $\beta$-adrenolytic activity remains unaffected. The particular metabolism of carvedilol could contribute to its long-term $\beta$-blocking activity [106]. It was reported [77] that in patients with chronic heart failure the plasma levels of carvedilol and its enantiomers were elevated in equilibrium state.

Hanioka et al. [107] described the stereoselective glucuronidation of carvedilol by UDP-glucuronosyltransferase in liver and in intestinal microsomes using racemic carvedilol and its enantiomers, respectively. As with other $\beta$-blockers, chiral HPLC was employed in the studies of pharmacokinetics of carvedilol. Graff [108] reports an increase in bioavailability and biological half-life of $(R)-(+)$-carvedilol upon combination with fluoxetine (an antidepressant).

With the exception of metoprolol, carvedilol, and propranolol, the influence of stereochemical configuration on the pharmacokinetics of $\beta$-blockers is only moderate. With acebutolol, higher plasma 
levels were attained with its (S)-(-)-enantiomer, probably as a result of first-pass metabolism of $(R)-(+)$-enantiomer [109].

Bisoprolol reaches bioavailability of around $90 \%$, due to its relatively minor first-pass effect. It is metabolized by cytochromes. Metabolization by CYP2D6 is stereoselective in favor of the (R)-enantiomer, whereas the metabolization by CYP3A4 is not stereoselective $[110,111]$. As shown by Kirsch [112], rifampicin (an activator of CYP3A4) produces a 30\% reduction in biological half-life of bisoprolol while cimetidine effects no significant changes in the pharmacokinetics of bisoprolol.

Timolol is for the greater part metabolized, approx. $20 \%$ of it, however, is eliminated unaltered. Besides the main metabolites formed by opening of the morpholine ring, oxidation of one of the methyl groups in the aminopropanol moiety takes place as well, yielding hydroxytimolol. Deamination and oxidation leads to derivatives of thiadiazolyloxoacetic acid. In vitro studies confirmed that timolol is metabolized mainly by CYP2D6 while CYP2C19 plays only minor role [113-115].

The main part of metipranolol is metabolized by desacetylation to desacetylmetipranolol during the first pass through the liver. This metabolite can be further oxidized to yield derivatives of butyric acid [116-118].

Atenolol is metabolized to a glucuronid. The oxidative hydroxylation of the methylene in the carbamoyl-methyl group provides hydroxyatenolol, which possesses approx. one tenth of the activity of atenolol $[119,120]$.

In comparison with the structure of metoprolol, betaxolol contains a cyclopropylalkyl group in position 4 of the phenol moiety, which gives rise to a slowdown of liver metabolism of this drug. Thus, betaxolol exhibits 6 times slower metabolism, twice higher bioavailability, and a prolongated biological half-life (16-22 h), as compared to metoprolol [121].

As reported by Beresford, betaxolol is metabolized in rats as well as in humans in a way similar to metoprolol, except that the cleavage of the cyclopropylmethyl group is slower. Merely $15 \%$ of betaxolol is subject to first pass metabolism [122].

The ester group present in the structure of esmolol undergoes rapid hydrolysis in blood, leading to quick onset of the pharmacological effect as well as its rapid abatement. Its metabolite, 3-\{4-[2-hydroxy-3-(propan-2-ylamino)propoxy]phenyl\}propionic acid, has 400 times lower activity toward $\beta_{1}$-receptors than esmolol [123].

Bopindolol acts as a prodrug, initially undergoing hydrolysis in the organism to provide the active form. In comparison with pindolol, which is excreted partly unaltered, partly as glucuronide and sulfate, the pharmacological effect of bopindolol sets on later but lasts longer $[123,124]$.

Labetolol contains two stereogenic centers and forms four stereoisomers. Its $(R R)$-isomer exhibits activity towards $\beta$-receptors while the (SR)-isomer is an $\alpha$-blocker. A minor part of the drug is excreted from organism in unchanged form, even though the main part is metabolized. The main metabolites are glucuronides, particularly alcohol glucuronides. Labetalol was titrated to male and female patients in order to achieve antihypertensive effect. The parameters were adjusted in accord with the dose. The fraction of the administered drug achieved in the biophase was $80 \%$ higher in women, even if the antihypertensive effect remained the same. This observation can be explained by differences in the concentrations of the $\alpha$-blocking (SR)-isomer and the relatively inactive (SS)- and (SR)-isomers (60\%-80\% higher in women) $[125,126]$.

Carvalho et al. reported stereoselectivity in the pharmacokinetics of labetalol after its oral administration, as a consequence of liver and first-pass metabolism. Lower levels of the $(R R)$ - and (SR)-enantiomers in blood plasma were confirmed by means of HPLC on a Chirobiotic V chiral columns and mobile phase consisting of methanol/acetic acid/diethylamine [127].

Bufuralol, another $\beta$-blocker of the aryloxyaminoethanol type, is metabolized on the basis of debrisoquin polymorphism. It reaches higher levels of the (S)-(-)-enantiomer in slow metabolizers. While the main metabolic pathway for $(R)-(-)$-bufuralol is aromatic hydroxylation, the $(S)-(+)$-bufuralol is metabolized predominantly by conjugation [128]. Both enantiomers undergo aliphatic hydroxylation, leading to the formation of two active diastereomers - alcohol and ketone, from (1'S)-bufuralol. 
The metabolites of $\left(1^{\prime} R\right)$-bufuralol exert minimum or no activity. It could be shown that the $\left(1^{\prime} R\right)$-enantiomer is hydroxylated thrice as much as the opposite enantiomer, yielding in both cases preferentially the product with 1 " $R$ chiral center $[129,130]$.

Nebivolol is classified as a third-generation $\beta$-blocker, employed chiefly in the therapy of hypertension and heart failure. It has four stereogenic centers and forms 32 stereoisomers. It binds predominantly to albumin and undergoes extensive first-pass metabolism via the cytochrome P4502D6 enzyme complex. It is mainly metabolized by aromatic hydroxylation, glucuronidation, and acyclic hydroxylation; to a lesser degree also by $N$-dealkylation $[131,132]$.

\subsection{Renal Excretion}

Impairment of the renal function can lead to accumulation in blood plasma of both enantiomers of $\beta$-blockers which are excreted to a large extent in unaltered state. These are mainly hydrophilic $\beta$-blockers such as atenolol, nadolol, and sotalol.

In comparison with metabolic transformations, the stereospecificity of renal excretion is low. This low degree of stereospecificity is probably based on active excretion and reuptake. Moderate stereospecificity of renal excretion in favour of $(R)-(+)$-metoprolol has no effect on its plasma levels, since it represents only a minor elimination pathway from plasma for this drug. Atenolol and pindolol exhibit increased concentration of the less active $(R)-(+)$-enantiomer due to stereospecific excretion of the (S)-(-)-isomer in urine.

The renal clearance of pindolol is affected also by co-administration of cimetidine, as cimetidine not only inhibits metabolism of some $\beta$-blockers (metoprolol, propranolol) but inhibits tubular excretion of a number of organic cations as well. $(R)-(+)$-pindolol, in particular, exhibits a $10 \%$ increase in plasma concentration as compared with the $(S)-(-)$-enantiomer. However, these findings regarding atenolol and pindolol are only of limited clinical significance [89].

\section{Stereoselective Analytical Methods in the Study of Pharmacokinetics of $\beta$-Blockers}

Stereoselective analytical methods for determination of the respective enantiomers in biological materials, especially in urine and plasma, are indispensable for the evaluation of pharmacokinetics and metabolism of $\beta$-blockers. At present, modern analytical techniques such as liquid chromatography with mass detection (LC-MS, LC-MS/MS) are used. Enantioseparation is carried out by means of chiral chromatographic stationary phases. In the case of $\beta$-blockers, chiral stationary phases based on macrocyclic antibiotics (teicoplanin and vancomycin) are often employed. Teicoplanin-based chiral phase (Chirobiotic T) was applied successfully in the analysis of enantiomers of metoprolol. Ion trap with electrospray (ESI) ionization in positive mode was used for the MS ion detection [133].

Chiral stationary phase Chirobiotic $\mathrm{T}$ and polar mobile phase (methanol/acetic acid/triethylamine) were employed in the pharmacokinetic studies of carvedilol [134] and acebutolol [135]. Chiral stationary phase containing vancomycin (Chirobiotic V) demonstrated efficiency in enantioseparation of atenolol, labetalol, and nebivolol [127,136,137].

Stereoselective analysis of acebutolol and its active metabolite diacetol in human plasma was accomplished by means of HPLC on a chiral phase containing cellobiohydrolase, in combination with quadrupole tandem mass spectrometry as the detector [138].

Other frequently used chiral phases employed in stereoselective bioanalyses of $\beta$-blockers encompass especially the polysaccharide-based stationary phases containing derivatives of cellulose and amylose $[139,140]$.

\section{Conclusions}

This survey deals with $\beta$-blockers of the arylaminoethanol type (sotalol, labetalol, bufuralol) and of the aryloxyaminopropanol type (penbutolol, betaxolol, esmolol, propranolol, betaxolol, timolol, carvedilol, nebivolol, and others). It outlines their different pharmacodynamic and pharmacokinetic properties as related to their stereochemical characteristics. 
In both categories of $\beta$-blockers higher activity towards $\beta$-receptors was observed in their (-)-isomers. These have the absolute configuration $(R)$ in arylaminoethanols and $(S)$ in aryloxyaminopropanols. Attempts to apply some $\beta$-blockers from the former category as pure enantiomers have not been successful. Thus, $(R)-(-)$-sotalol had to be removed from clinical practice because of increased mortality. In addition, $(R, R)-(-)$-labetalol (dilevalol; a non-selective $\beta$-blocker/selective $\alpha 1$-blocker) was discontinued due to the observed hepatotoxicity.

Aryloxyaminopropanols generally exert higher $\beta$-blocking activity in comparison with the former category. Several drugs from this group have found their way into clinical practice as optically pure enantiomers, such as the (S)-(-)-enantiomers of penbutolol (Betapressin ${ }^{\circledR}$ ), levobunolol (Vistigan ${ }^{\circledR}$ ), timolol (Dispatim ${ }^{\circledR}$ ), and atenolol (Atpure ${ }^{\circledR}$ ) used in the therapy of hypertension, as well as $(S)-(-)$-bunolol (levobunolol; Betagan $\left.{ }^{\circledR}\right)$ and $(S)-(-)$-betaxolol (levobetaxolol; Betagan ${ }^{\circledR}$ ) applied in the treatment of glaucoma.

The distinct pharmacokinetic phases (resorption, distribution, and metabolism) of particular $\beta$-blockers have been investigated; nevertheless, in most cases the available experimental data concerning the differences in their activity in dependence on the specific stereochemical configuration of the enantiomers is insufficient. Thus, there is still much research to be done on the $\beta$-blockers already established in the clinical practice, which could lead to introduction of optically pure enantiomers of these drugs instead of racemic mixtures, with improved activity and/or toxicity profile (so-called "chiral switch").

Author Contributions: Conceptualization, R.Č.; investigation, R.Č., L.H., M.M., J.V.; visualization, L.H., R.Č. and M.M.; writing—original draft preparation, R.Č. and L.H.; writing—review \& editing, R.Č., L.H. and J.V.

Funding: This work has been supported by the Scientific Grants Agency of the Slovak Republic (Project No. $1 / 0346 / 16)$. The funders had no role in the design of the study; in the collection, analyses, or interpretation of data; in the writing of the manuscript, or in the decision to publish the results.

Conflicts of Interest: The authors declare no conflict of interest.

\section{References}

1. Lechat, P.; Volta, S.D.; Cannon, C.P. Clinical pharmacology of beta-blockers in cardiology trial results and clinical application. Hot Top. Cardiol. 2008, 10, 7-44. [CrossRef]

2. Saxena, R.; Prakash, J.; Mathur, P.; Gupta, S.K. Pharmacotherapy of glaucoma. Ind. J. Pharmacol. 2002, 34, 71-85.

3. Sharma, R.; Shastri, N.; Sadhotra, P. $\beta$-Blockers as glaucoma therapy. JK Sci. 2007, 9, 42-45.

4. Dooley, T.P. Treating anxiety with either beta blockers or antiemetic antimuscarinic drugs: A review. Ment. Health Fam. Med. 2015, 11, 89-99. [CrossRef]

5. Feely, J.; Peden, N. Use of beta-adrenoceptor blocking drugs in hyperthyroidism. Drugs 1984, 27, 425-446. [CrossRef] [PubMed]

6. Pérez-Castrillón, J.L.; De Luis, D.A.; Duenas-Laita, A. Are beta-blockers useful in the prevencion of osteoporotic fractures? Eur. Rev. Med. Pharmacol. Sci. 2009, 13, 157-162. [PubMed]

7. Migliazzo, C.V.; Hagan, J.C. Beta blocker eye drops for treatment of acute migraine. Mo. Med. 2014, 111, 283-288.

8. Rehsia, N.S.; Dhalla, N.S. Mechanisms of the beneficial effects of beta-adrenoceptor antagonists in congestive heart failure. Exp. Clin. Cardiol. 2010, 15, e86-e95. [PubMed]

9. Weber, M.A. The role of the new beta-blockers in treating cardiovascular disease. Am. J. Hypertens. 2005, 18, 169S-176S. [CrossRef]

10. Emmirati, E.; Contri, R.; Coppini, R.; Ceachi, F.; Frigerio, M.; Olivotto, I. Pharmacological treatment of hypertrophic cardiomyopathy: Current practice and novel perspectives. Eur. J. Heart Fail. 2016, 18, 1106-1118. [CrossRef] [PubMed]

11. Tobe, S.W. $\beta$-adrenergic receptor blockers in hypertension. Can. J. Cardiol. 2014, 30, 1-2. [CrossRef] [PubMed]

12. Larochelle, P.; Tobe, S.W.; Lacourcière, Y. $\beta$-blockers in hypertension: Studies and meta-analyses over the years. Can. J. Cardiol. 2014, 30, 16-22. [CrossRef] [PubMed] 
13. Weir, M.R. Beta-blockers in the treatment of hypertension: Are there clinically relevant differences? Postgrad. Med. 2009, 121, 90-98. [CrossRef] [PubMed]

14. Cruickshank, J.M. Beta-blockers and heart failure. Indian Heart J. 2010, 62, 101-110. [PubMed]

15. Bruchatá, K.; Čižmáriková, R. New derivatives of aryloxyaminopropanol—Structure biological activity relationship (slovak). Farm. Obzor 2010, 79, 237-293.

16. Poirier, L.; Tobe, S.W. Contemporary use of $\beta$-blockers: Clinical relevance of subclassification. Can. J. Cardiol. 2014, 30 (Suppl. 5), S9-S15. [CrossRef] [PubMed]

17. Cahn, R.S.; Ingold, C.K.; Prelog, V. Specification of molecular chirality. Angew. Chem. Int. Ed. 1966, 5, $385-415$. [CrossRef]

18. Prelog, V.; Helmchen, G. Basic principles of the CIP-system and proposals for a revision. Angew. Chem. Int. Ed. 1982, 21, 567-583. [CrossRef]

19. Ariëns, E.J. Stereochemistry, a basis for sophisticated nonsense in pharmacokinetics and clinical pharmacology. Eur. J. Clin. Pharmacol. 1984, 26, 663-668. [CrossRef]

20. Lehmann, F.P.A.; Rodriques de Miranda, J.F.; Ariëns, E.J. Stereoselectivity and affinity in molecular pharmacology. III. Structural aspects in the mode of action of natural and synthetic auxins. Chem. Biol. Interact. 1978, 20, 101-142. [CrossRef]

21. Ariëns, E.J. Racemic therapeutics - ethical and regulatory aspects. Eur. J. Clin. Pharmacol. 1991, 41, 89-93. [CrossRef] [PubMed]

22. Čižmáriková, R. $\beta$-Adrenergic receptor blockers-The group of chiral drugs: Different effects of individual enantiomers. Čes. Slov. Farm. 2002, 51, 121-128.

23. Agustian, J.; Kamaruddin, A.H.; Bhatia, S. Enantiomeric $\beta$-blockers-The existing technologies. Process Biochem. 2010, 45, 1587-1604. [CrossRef]

24. Nagatomo, T.; Koike, K. Recent advance in structure, binding sites with ligands and pharmacological function of $\beta$-adrenoceptors obtained by molecular biology and molecular modeling. Life Sci. 2000, 66, 2419-2426. [CrossRef]

25. Glover, W.E.; Greenfield, A.D.M.; Shanks, R.G. Effect of dichloroisoprenaline on the peripheral vascular responses to adrenaline in man. Br. J. Pharmacol. Chemother. 1962, 19, 235-244. [CrossRef] [PubMed]

26. Almirante, L.; Murmann, W. Relationship between configuration and adrenergic $\beta$-receptor blocking activity of optical isomers of 1-(4-nitrophenyl)-2-isopropylaminoethanol (INPEA). J. Med. Chem. 1966, 9, 650-653. [CrossRef] [PubMed]

27. Petrongolo, C.; Tomasi, J.; Macchia, B.; Macchia, M. Molecular orbital studies on the mechanism of drug-receptor interaction. 1. Adrenergic drugs. Conformation and reactivity of isoproterenol and 1-(p-nitrophenyl)-2-isopropylaminoethanol. J. Med. Chem. 1974, 17, 501-507. [CrossRef]

28. Black, J.W.; Stephenson, J.S. Pharmacology of a new adrenergic beta-receptor-blocking compound (Nethalide). Lancet 1962, 280, 311-314. [CrossRef]

29. Howe, R.; Rao, B.S. Beta-adrenergic blocking agents. III. The optical isomers of pronethalol, propranolol, and several related compounds. J. Med. Chem. 1968, 11, 1118-1121. [CrossRef]

30. Lucchesi, B.R. The effects of pronethalol and its dextro isomer upon experimental cardiac arrhythmias. J. Pharmac. Exp. Ther. 1965, 148, 94-99.

31. Paget, G.E. Carcinogenic action of pronethalol. Br. J. Pharmacol. 1963, 2, 1266-1267. [CrossRef]

32. Cho, B.T.; Kang, S.K.; Yang, W.K. Convenient synthesis of enantiopure $\beta$-adrenergic blockers: (R)-nifenalol, (R)-denopamine, (R)-dichloroisoproterenol and (R)-pronethalol. Bull. Korean Chem. Soc. 2002, 23, 1328-1330. [CrossRef]

33. Saddique, F.A.; Zahoor, A.F.; Yousaf, M.; Irfan, M.; Ahmad, M.; Mansha, A.; Khan, Z.A.; Naqvi, S.A.R. Synthetic approaches towards the synthesis of beta-blockers (betaxolol, metoprolol, sotalol, and timolol). Turk. J. Chem. 2016, 40, 193-224. [CrossRef]

34. Funck-Brentano, C. Pharmacokinetic and pharmacodynamic profiles of d-sotalol and d,l-sotalol. Eur. Heart J. 1993, 14 (Suppl. H), 30-35. [CrossRef] [PubMed]

35. Salazar, D.E.; Much, D.R.; Nichola, P.S.; Seibold, J.R.; Shindler, D.; Slugg, P.H. A pharmacokineticpharmacodynamic model of d-sotalol Q-Tc prolongation during intravenous administration to healthy subjects. J. Clin. Pharmacol. 1997, 37, 799-809. [CrossRef] 
36. Waldo, A.; Camm, A.; de Ruyter, H.; Friedman, P.; MacNeil, D.; Pauls, J.; Pitt, B.; Pratt, C.; Schwartz, P.; Veltri, E. Effect of d-sotalol on mortality in patients with left ventricular dysfunction after recent and remote myocardial infarction. Lancet 1996, 348, 7-12. [CrossRef]

37. Brogden, R.N.; Heel, R.C.; Speight, T.M.; Avery, G.S. Labetalol: A review of its pharmacology and therapeutic use in hypertension. Drugs 1978, 15, 251-270. [CrossRef]

38. Riva, E.; Mennini, T.; Latini, R. The alpha- and beta-adrenoceptor blocking activities of labetalol and its RR-SR (50:50) stereoisomers. Br. J. Pharmacol. 1991, 104, 823-828. [CrossRef]

39. Nagy, B.; Dima, N.; Paizs, C.; Brem, J.; Irimie, F.D.; Toşa, M.I. New chemo-enzymatic approaches for the synthesis of (R)- and (S)-bufuralol. Tetrahedron Asymmetry 2014, 25, 1316-1322. [CrossRef]

40. Pringle, T.H.; Francis, R.J.; East, P.B.; Shanks, R.G. Pharmacodynamic and pharmacokinetic studies on bufuralol in man. Br. J. Clin. Pharmacol. 1986, 22, 527-534. [CrossRef]

41. Hamilton, T.C.; Parkes, M.W. Bufuralol a new $\beta$-adrenoceptor blocking agent in a series of benzofuran-2-ethanolamines. Arzneim. Forsch. (Drug Res.) 1977, 27, 1410-1417.

42. Forthegill, G.A.; Osbond, J.M.; Wickens, J.C. Bufuranol, a new $\beta$-adrenoceptor blocking agent. Part 1: Synthesis and structure activity studies in a series of benzofuran-2-ethanol amines. Arzneim. Forsch. (Drug Res.) 1977, 27, 978-981.

43. Meier, M.; Hedwall, P.R.; Imhof, P.; Wilhelm, M.; Brunner, H. Untersuchungen mit den optischen Antipoden der adrenergischen $\beta$-Receptoren Blockers 1-(o-Allyloxy-phenoxy)-3-isopropylamino-2-propranolol. Arzneim. Forsch. (Drug Res.) 1970, 20, 1890-1896.

44. Buckner, C.K.; Patil, P.N. The rate of onset of $\beta$-adrenergic blockade by the optical isomers of alprenolol. Eur. J. Pharmacol. 1971, 14, 308-311. [CrossRef]

45. Belliveau, R.E.; Covino, B.G. Effects of a new $\beta$-adrenergic receptor blocking agent, alprenolol, and its optical isomers. Arch. Int. Pharmacodyn. 1969, 180, 341-349. [PubMed]

46. Duce, B.R.; Garberg, L.; Smith, E.R. Effects of $( \pm)$-propranolol, ( \pm )-, (+)-, and (-)-alprenolol on unanaesthetized dogs with ventricular arrhythmias resulting from coronary artery ligation. Br. J. Pharmacol. 1970, 39, 809-816. [CrossRef] [PubMed]

47. Saunamäki, K. Studies on the anti-arrhythmic effect of dextro-alprenolol. Investigation of the anti-arrhythmic effect of dextro-alprenolol. Eur. J. Clin. Pharmacol. 1970, 3, 23-31. [CrossRef]

48. Vohra, J.K.; Thompson, P.L.; Sloman, J.G. Clinical experience with dextro-alprenolol. Br. Med. J. 1970, 1, 791-792. [CrossRef]

49. Porciatti, F.; Cerbai, E.; Masini, I.; Mugelli, A. Electrophysiological evaluation of the beta-blocking properties and direct membrane effects of l-moprolol and its enantiomer d-moprolol. Arch. Int. Pharmacodyn. Ther. 1989, 299, 200-209.

50. Hartfelder, G.; Lessenich, H.; Schmitt, K. Penbutolol (Hoe 893 d), ein neues, stark wirksames Sympatholytikum mit langer Wirkungsdauer. Arzneim. Forsch. (Drug Res.) 1972, 22, 930-932.

51. Dogrell, S.A. Effects of (+/-)- (+)- and (-)-metoprolol, (+/-)- (+)- and (-)-pindolol, (+/-)-mepindolol and (+/-)-bopindolol on the rat left atria and portal vein. Gen. Pharmacol. 1991, 22, 1169-1177. [CrossRef]

52. Mohan, J.C.; Shah, S.N.; Chinchansurkar, S.; Dey, A.; Jain, R. Rediscovering chirality - role of S-metoprolol in cardiovascular disease management. J. Assoc. Physicians India 2017, 65, 74-79. [PubMed]

53. Sharif, N.A.; Xu, S.X.; Crider, J.Y.; McLaughlin, M.; Davis, T.L. Levobetaxolol (Betaxon) and other beta-adrenergic antagonists: Preclinical pharmacology, IOP-lowering activity and sites of action in human eyes. J. Ocul. Pharmacol. Ther. 2001, 17, 305-317. [CrossRef] [PubMed]

54. Osborne, N.N.; Wood, J.P.; Chidlow, G.; Casson, R.; DeSantis, L.; Schmidt, K.G. Effectiveness of levobetaxolol and timolol at blunting retinal ischaemia is related to their calcium and sodium blocking activities: Relevance to glaucoma. Brain Res. Bull. 2004, 62, 525-528. [CrossRef]

55. Quaranta, L.; Turano, R.; Pizzolante, T. Levobetaxolol hydrochloride: A review of its pharmacology and use in the treatment of chronic open-angle glaucoma and ocular hypertension. Clin. Ophthalmol. 2007, 1, 93-97. [PubMed]

56. Sum, C.Y.; Yacobi, A.; Kartzinel, R.; Stampfli, H.; Davis, C.S.; Lai, C.M. Kinetics of esmolol, an ultra-short-acting beta blocker, and of its major metabolite. Clin. Pharmacol. Ther. 1983, 34, 427-434. [CrossRef] [PubMed] 
57. Volz-Zang, C.; Eckrich, B.; Jahn, P.; Schneidrowski, B.; Schulte, B.; Palm, D. Esmolol, an ultrashort-acting, selective beta 1-adrenoceptor antagonist: Pharmacodynamic and pharmacokinetic properties. Eur. J. Clin. Pharmacol. 1994, 46, 399-404. [CrossRef] [PubMed]

58. Jaillon, P.; Drici, M. Recent antiarrhythmic drugs. Am. J. Cardiol. 1989, 64, 65J-69J. [CrossRef]

59. Deng, C.Y.; Lin, S.G.; Zhang, W.C.; Kuang, S.J.; Qian, W.M.; Wu, S.L.; Shan, Z.X.; Yang, M.; Yu, X.Y. Esmolol inhibits $\mathrm{Na}^{+}$current in rat ventricular myocytes. Methods Find. Exp. Clin. Pharmacol. 2006, 28, 697-702. [CrossRef]

60. Quon, C.Y.; Mai, K.; Patil, G.; Stampfli, H.F. Species differences in the stereoselective hydrolysis of esmolol by blood esterases. Drug Metab. Dispos. 1988, 16, 425-428.

61. Okamura, M.; Kumagai, M.; Murasaki, Y.; Ohkura, T.; Miyamoto, Y.; Kawai, Y.; Tamura, T.; Takariki, Y.; Tomisawa, H. Stereoselective pharmacokinetics of esmolol enantiomers. Xenobio. Metabol. Dispos. 2001, 16, 427-435. [CrossRef]

62. Dogrel, S.A. Effects of (+/-)-, (+)- and (-)-celiprolol on the rat left atria and portal vein. J. Pharm. Pharmacol. 1992, 44, 239-243. [CrossRef]

63. Howe, R.; Shanks, R.G. Optical isomers of propranolol. Nature 1966, 210, 1336-1338. [CrossRef] [PubMed]

64. Stoschitzky, K.; Lindner, W.; Kiowski, W. Stereoselective vascular effects of the (R)- and (S)-enantiomers of propranolol and atenolol. J. Cardiovasc. Pharmacol. 1995, 25, 268-272. [CrossRef] [PubMed]

65. Barrett, A.M.; Cullum, V.A. The biological properties of the optical isomers of propranolol and their effect on cardiac arrhythmias. Br. J. Pharmacol. 1968, 34, 43-55. [CrossRef] [PubMed]

66. Bode, W.; Toet, A.E.; Stolker, A.A.; van Ginkel, L.A.; Groen, K.; Wermer, J.; de Wildt, D.J. Toxicokinetics of a single intravenous dose of rac-propranolol versus optically pure propranolol in the rat. Chirality 1995, 7, 626-631. [CrossRef] [PubMed]

67. Toet, A.E.; van de Kuil, A.; Vleeming, W.; Wemer, J.; Bode, W.; Meulenbelt, J.; de Wildt, D.J. Toxic doses of rac-, (-)-(S)- and (+)-(R )-propranolol in rats and rabbits. Chirality 1996, 8, 411-417. [CrossRef]

68. Stanley, J.K.; Ramirez, A.J.; Mottaleb, M.; Chambliss, C.K.; Brooks, B.W. Enantiospecific toxicity of the beta-blocker propranolol to Daphnia magna and Pimephales promelas. Environ. Toxicol. Chem. 2006, 25, 1780-1786. [CrossRef]

69. Midha, K.; McKay, G.; Rawson, M.J.; Hubbard, J.W. The impact of stereoisomerism in bioequivalence studies. J. Pharm. Sci. 1998, 87, 797-802. [CrossRef]

70. Evans, D.B.; Peschka, M.T.; Lee, R.J.; Laffan, R.J. Anti-arrhythmic action of nadolol, a beta-adrenergic receptor blocking agent. Eur. J. Pharmacol. 1976, 35, 17-27. [CrossRef]

71. Wheeldon, N.M.; McDevitt, D.G.; Lipworth, B.J. The effects of lower than conventional doses of oral nadolol on relative beta 1/beta 2-adrenoceptor blockade. Br. J. Clin. Pharmacol. 1994, 38, 103-108. [CrossRef] [PubMed]

72. Quast, U.; Vollmer, K.O. Binding of beta-adrenoceptor antagonists to rat and rabbit lung: Special reference to levobunolol. Arzneim. Forsch. (Drug. Res.) 1984, 34, 579-584.

73. Dong, Y.; Ishikawa, H.; Wu, Y.; Yoshitomi, T. Vasodilatory mechanism of levobunolol on vascular smooth muscle cells. Exp. Eye Res. 2007, 84, 1039-1046. [CrossRef] [PubMed]

74. Gonzalez, J.P.; Clissold, S.P. Ocular levobunolol. A review of its pharmacodynamic and pharmacokinetic properties, and therapeutic efficacy. Drugs 1987, 34, 648-661. [CrossRef]

75. Karhuvaara, S.; Kaila, T.; Huupponen, R. Beta-adrenoceptor antagonist activities and binding affinities of timolol enantiomers in rat atria. J. Pharm. Pharmacol. 1989, 41, 649-650. [CrossRef] [PubMed]

76. Brown, C. Chirality in Drug Design and Synthesis; Academic Press: New York, NY, USA, 1990; pp. $10-11$.

77. Tenero, D.; Boike, S.; Boyle, D.; Ilson, B.; Fesniak, H.F.; Brozena, S.; Jorkasky, D. Steady-state pharmacokinetics of carvedilol and its enantiomers in patients with congestive heart failure. J. Clin. Pharmacol. 2000, 40, 844-853. [CrossRef] [PubMed]

78. Siebert, C.D.; Hänsicke, A.; Nagel, T. Stereochemical comparison of nebivolol with other beta-blockers. Chirality 2008, 20, 103-109. [CrossRef] [PubMed]

79. Ignarro, L.J. Different pharmacological properties of two enantiomers in a unique beta-blocker, nebivolol. Cardiovasc. Ther. 2008, 26, 115-134. [CrossRef]

80. Sacco, G.; Evangelista, S.; Criscuoli, M.; Goso, C.; Bigioni, M.; Binaschi, M.; Manzini, S.; Maggi, C.A. Involvement of nitric oxide in both central and peripheral haemodynamic effect of D/L-nebivolol and its enantiomers in rats. Eur. J. Pharmacol. 2005, 511, 167-174. [CrossRef] 
81. De Groot, A.A.; Mathy, M.J.; van Zwieten, P.A.; Peters, S.L. Antioxidant activity of nebivolol in the rat aorta. J. Cardiovasc. Pharmacol. 2004, 43, 148-153. [CrossRef]

82. Mason, R.P.; Kubant, R.; Jacob, R.F.; Walter, M.F.; Boychuk, B.; Malinski, T. Effect of nebivolol on endothelial nitric oxide and peroxynitrite release in hypertensive animals: Role of antioxidant activity. J. Cardiovasc. Pharmacol. 2006, 48, 862-869. [CrossRef] [PubMed]

83. Benedetti, M.S.; Whomsley, R.; Poggesi, I.; Cawello, W.; Mathy, F.-X.; Delporte, M.-L.; Papeleu, P.; Watelet, J.-B. Drug metabolism and pharmacokinetics. Drug. Metab. Rev. 2009, 41, 344-390. [CrossRef] [PubMed]

84. Račanská, E.; Švec, P. Využitie $\beta$-blokátorov v súčasnej terapii a perspektívy ich d'alšieho vývoja. Farm. Obzor 1997, 66, 63-66.

85. Taylor, D.C.; Pownall, R.; Burke, W. The absorption of beta-adrenoceptor antagonists in rat in-situ small intestine; the effect of lipophilicity. J. Pharm. Pharmacol. 1985, 37, 280-283. [CrossRef]

86. Mehvar, R.; Brocks, D.R. Stereospecific pharmacokinetics and pharmacodynamics of beta-adrenergic blockers in humans. J. Pharm. Pharm. Sci. 2001, 4, 185-200. [PubMed]

87. Mehvar, R.; Brocks, D.R. Stereospecific pharmacokinetics and pharmacodynamics: Cardiovascular drugs. In Chirality in Drug Design and Development; Reddy, I.K., Mehvar, R., Eds.; Marcel Dekker: New York, NY, USA, 2004; pp. 281-350.

88. Takahashi, H.; Ogata, H.; Kanno, S.; Taskeuchi, H. Plasma protein binding of propranolol enantiomers as a major determinant of their stereoselective tissue distribution in rats. J. Pharmacol. Exp. Ther. 1990, 252, 272-278. [PubMed]

89. Yan, H.; Levander, T. Differential tissue distribution of the enantiomers of racemic pindolol in the rat. Eur. Neuropsychopharmacol. 1999, 10, 59-62. [CrossRef]

90. Rodgers, T.; Leahy, D.; Rowland, M. Tissue distribution of basic drugs: Accounting for enantiomeric compound and regional differences amongst beta-blocking drugs in rat. J. Pharm. Sci. 2005, 94, 1237-1248. [CrossRef]

91. Ďuricová, J.; Grundmann, M. CYP2D6 a jeho klinický význam. Klin. Farmakol. Farm. 2007, 21, $133-136$.

92. Narimatsu, S.; Nakata, T.; Shimizudani, T.; Nagaoka, K.; Nakura, H.; Masuda, K.; Katsu, T.; Koeda, A.; Naito, S.; Yamano, S.; et al. Regio- and stereoselective oxidation of propranolol enantiomers by human CYP2D6, cynomolgus monkey CYP2D17 and marmoset CYP2D19. Chem. Biol. Interact. 2011, 189, 146-152. [CrossRef]

93. Shimizudani, T.; Nagaoka, K.; Hanioka, N.; Yamano, S.; Narimatsu, S. Comparative study of the oxidation of propranolol enantiomers in hepatic and small intestinal microsomes from cynomolgus and marmoset monkeys. Chem. Biol. Interact. 2010, 183, 67-78. [CrossRef] [PubMed]

94. Yu, L.; Oian, M.; Liu, Y.; Yao, T.; Zeng, S. Stereoselective metabolism of propranolol glucuronidation by human UDP-glucuronosyltransferases 2B7 and 1A9. Chirality 2010, 22, 456-461. [CrossRef] [PubMed]

95. Yoshimoto, K.; Echizen, H.; Chiba, K.; Tani, M.; Ishizaki, T. Identification of human CYP isoform involved in the metabolism of propranolol enantiomers- $\mathrm{N}$-desisopropylation is mediated mainly by CYP1A2. Br. J. Clin. Pharmacol. 1995, 39, 421-431. [CrossRef] [PubMed]

96. Donn, K.; Powell, J.; Weiner, I. Stereoselectivity of cimetidine inhibition of propranolol oral clearance. Clin. Pharmacol. Ther. 1985, 37, 191.

97. Zhou, H.H.; Anthony, L.B.; Roden, D.M.; Wood, A.J. Quinidine reduces clearance of (+)-propranolol more than (-)-propranolol through marked reduction in 4-hydroxylation. Clin. Pharmacol. Ther. 1990, 47, 686-693. [CrossRef] [PubMed]

98. Tongwei, Y.; Yan, C. Selective role of cytochrome P450 isoenzymes in metabolism-depend binding of $\beta$-adrenoceptor antagonist to liver microsomal protein in rats. Zhejang Daxue Xuebao Yixueban 2001, 30, 197-200.

99. Walle, T.; Walle, U.; Conradi, E. Pathway-selective sex differences in the metabolic clearance of propranolol in human subjects. Clin. Pharmacol. Ther. 1989, 46, 257-263. [CrossRef]

100. Mistry, B.; Leslie, J.I.; Eddington, N.D. Influence of input rate on the stereospecific and nonstereospecific first pass metabolism and pharmacokinetics of metoprolol extended release formulations. Chirality 2002, 14, 297-304. [CrossRef]

101. Cergueira, P.M.; Cesarino, E.J.; Bertucci, C.; Bonato, P.S.; Lanchote, V.L. Stereoselective metabolism of metoprolol: Enantioselectivity of $\alpha$-hydroxymetoprolol in plasma and urine. Chirality 2003, 15, 542-549. [CrossRef] 
102. Boralli, V.B.; Coelho, E.B.; Cerqueira, P.M.; Lanchote, V.L. Stereoselective analysis of metoprolol and its metabolite in rat plasma with application to oxidative metabolism. J. Chromatogr. B 2005, 823, 195-202. [CrossRef]

103. Seeringer, A.; Brockmöller, J.; Bauer, S.; Kirchheiner, J. Enantiospecific pharmacokinetics of metoprolol in CYP2D6 ultra-rapid metabolizers and correlation with exercise-induced heart rate. Eur. J. Clin. Pharmacol. 2008, 64, 883-888. [CrossRef] [PubMed]

104. Brodde, O.E.; Kroemer, H.K. Drug-drug interaction of $\beta$-adrenoceptor blockers. Arzneim. Forsch. (Drug. Res.) 2003, 12, 814-822. [CrossRef] [PubMed]

105. Peřinová, I.; Ďuricová, J.; Brozmanová, H.; Kacířová, I.; Grundmann, M. Stanovení metoprololu a jeho metabolitu alfa-hydroxymetoprololu v sére metódou HPLC s fluorescenční detekcí. Česk. Slov. Farm. 2008, 57, 254-259.

106. Zhou, H.H.; Wood, A.J. Stereoselective disposition of carvedilol is determined by CYP2D6. Clin. Pharmacol. Ther. 1995, 57, 518-524. [CrossRef]

107. Hanioka, N.; Tanaka, S.; Moriguchi, Y.; Narimatsu, S. Stereoselective glucuronidation of carvedilol in human liver and intestinal microsomes. Pharmacology 2012, 90, 117-124. [CrossRef] [PubMed]

108. Graff, D.W.; Williamson, K.M.; Pieper, J.A.; Carson, S.W.; Adams, K.F.; Cascio, W.E.; Patterson, J.H. Effect of fluoxetine on carvedilol pharmacokinetics, CYP2D6 activity, and autonomic balance in heart failure patients. J. Clin. Pharmacol. 2001, 41, 97-106. [CrossRef] [PubMed]

109. Piquette-Miller, M.; Foster, R.T.; Kappagoda, C.T.; Jamali, F. Pharmacokinetics of acebutolol enantiomers in humans. J. Pharm. Sci. 1991, 80, 313-316. [CrossRef] [PubMed]

110. Horikiri, Y.; Suzuki, T.; Mizobe, M. Stereoselective pharmacokinetics of bisoprolol after intravenous and oral administration in beagle dogs. J. Pharm. Sci. 1997, 86, 560-564. [CrossRef]

111. Horikiri, Y.; Suzuki, T.; Mizobe, M. Pharmacokinetics and metabolism of bisoprolol enantiomers in humans. J. Pharm. Sci. 1998, 87, 289-294. [CrossRef]

112. Kirsch, W.; Rose, I.; Klingmann, I.; Pabst, J.; Ohnhaus, E.E. Interaction of bisoprolol with cimetidine and rifampicin. Eur. J. Clin. Pharmacol. 1986, 31, 59-62. [CrossRef]

113. Nieminen, T.; Uusitalo, H.; Mäenpää, J.; Turjanmaa, V.; Rane, A.; Lundgren, S.; Ropo, A.; Rontu, R.; Lehtimäki, T.; Kähönen, M. Polymorphisms of genes CYP2D6, ADRB1 and GNAS1 in pharmacokinetics and systemic effects of ophthalmic timolol. A pilot study. Eur. J. Clin. Pharmacol. 2005, 61, 811-819. [CrossRef] [PubMed]

114. Volotinen, M.; Turpeinen, M.; Tolonen, A.; Uusitalo, J.; Mäenpää, J.; Pelkonen, O. Timolol metabolism in human liver microsomes is mediated principally by CYP2D6. Drug Metab. Dispos. 2007, 35, 1135-1141. [CrossRef] [PubMed]

115. Volotinen, M.; Hakkola, J.; Relkonen, O.; Vapaatalo, H.; Mäenpää, J. Metabolism of ophthalmic timolol: New aspects of an old drug. Basic Clin. Pharmacol. Toxicol. 2011, 108, 297-303. [CrossRef] [PubMed]

116. Gvozdják, J.; Gvozdjaková, A.; Kucharská, J.; Bada, V.; Baranyai, A.; Drímal, J. The effect of trimepranol on metabolism in the ischemic heart muscle. Vnitr. Lek. 1985, 31, 209-215. [PubMed]

117. Abshagen, U.; Betzien, G.; Kaufmann, B.; Endele, G. Pharmacokinetics of metipranolol in normal man. Eur. J. Clin. Pharmacol. 1982, 21, 293-301. [CrossRef]

118. Maffei Facino, R.; Bertuletti, R.; Carini, M.; Tofanetti, O. In vitro metabolism of methylpranolol by rat liver. Anal. Chem. Symp. Ser. 1980, 4, 217-223.

119. Kirch, W.; Görg, K.G. Clinical pharmacokinetics of atenolol—A review. Eur. J. Drug Met. Pharmacokin. 1982, 7, 81-91. [CrossRef]

120. Stoschitzky, K.; Egginger, G.; Zernig, G.; Klein, W.; Lindner, W. Stereoselective features of (R) and (S)-atenolol: Clinical pharmacological, pharmacokinetic, and radioligand binding studies. Chirality 1993, 5, 15-19. [CrossRef]

121. Manoury, P.M.; Binet, J.L.; Rousseau, J.; Lefebre-Borg, F.M.; Cavero, I.G. Synthesis of a series compounds related to betaxolol, a new $\beta_{1}$-adrenoceptor antagonist with a pharmacological and pharmacokinetic profile optimized for the treatment of chronic cardiovascular diseases. J. Med. Chem. 1987, 30, 1003-1011. [CrossRef]

122. Beresford, R.; Heel, R.C. Betaxolol of its pharmacodynamic and pharmacokinetic properties, and therapeutic efficacy in hypertension. Drugs 1986, 31, 6-28. [CrossRef]

123. Marko, V. Determination of Beta-Blockers in Biological Material; Elsevier Science Publishers: Amsterdam, The Netherlands, 2013. 
124. Goncalves, P.V.; Mattes, A.C.; Da Cunha, S.P.; Lanchote, V.L. Enantioselectivity in the steady-state pharmacokinetics and transplacental distribution of pindolol at delivery in pregnancy-induced hypertension. Chirality 2002, 14, 683-687. [CrossRef] [PubMed]

125. MacCarthy, E.P.; Bloomfield, S.S. Labetalol: A review of its pharmacology, pharmacokinetics, clinical uses and adverse effects. Pharmacotherapy 1983, 3, 193-219. [CrossRef] [PubMed]

126. Johnson, J.A.; Akers, W.S.; Herring, V.L.; Wolfe, M.S.; Sullivan, J.M. Gender differences in labetalol kinetic: Importance of determing stereoisomers kinetics for racemic drugs. Pharmacotherapy 2000, 20, 622-628. [CrossRef] [PubMed]

127. Carvalho, T.M.; Cavalli, R.C.; Marques, M.P.; Da Cunha, S.P.; Baraldi, C.O.; Lanchote, V.L. Stereoselective analysis of labetalol in human plasma by LC-MS/MS: Application to pharmacokinetics. Chirality 2009, 21, 738-744. [CrossRef] [PubMed]

128. Weerawarna, S.A.; Geisshusler, S.M.; Murthy, S.S.; Nelson, W.L. Enantioselective and diastereoselective hydroxylation of bufuranol. Absolute configuration of the 7-(1-hydroxyethyl)-2-[1-hydroxy-2-(tertbutylamino)ethyl]benzofurans, the benzylic hydroxylation metabolites. J. Med. Chem. 1991, 34, 3091-3097. [CrossRef] [PubMed]

129. Narimatsu, S.; Satoh, T.; Meyer, U.A.; Gonzales, F.J. Stereoselective metabolism of bufuralol racemate and enantiomers in human liver microsomes. J. Pharmacol. Exp. Ther. 2002, 303, 172-178. [CrossRef] [PubMed]

130. Masuda, K.; Tamagake, K.; Okuda, Y.; Torigoe, F.; Tsuzuki, D.; Isobe, T.; Hichiya, H.; Hanioka, N.; Yamamoto, S.; Narimatsu, S. Change in enantioselectivity in bufuralol 1"-hydroxylation by the substitution of phenylalanine-120 by alanine in cytochrome P450 2D6. Chirality 2005, 17, 37-43. [CrossRef]

131. Hillas, O.; Ezzo, D. Nebivolol (Bystolic), a novel beta blocker for hypertension. Pharm. Ther. 2009, 34, 188-192.

132. Sanaee, F.; Neves, D.V.; Lanchote, V.L.; Jamali, F. Pharmacokinetics of nebivolol in the rat: Low oral absorption, loss in the gut and systemic stereoselectivity. Biopharm. Drug Dispos. 2013, 34, 312-320. [CrossRef]

133. Jensen, B.P.; Sharp, C.F.; Gardiner, S.J.; Begg, E.J. Development and validation of a stereoselective liquid chromatography-tandem mass spectrometry assay for quantification of S- and R- metoprolol in human plasma. J. Chromatogr. B 2008, 865, 48-54. [CrossRef]

134. Poggi, J.C.; Da Silva, F.G.; Coelho, E.B.; Marques, M.P.; Bertucci, C.; Lanchote, V.L. Analysis of carvedilol enantiomers in human plasma using chiral stationary phase column and liquid chromatography with tandem mass spectrometry. Chirality 2012, 24, 209-214. [CrossRef] [PubMed]

135. Al-Omar, M.A. Stereoselective HPLC assay of acebutolol enantiomers with fluorescence detection and its application to a pharmacokinetic study. World Appl. Sci. J. 2010, 8, 1309-1316.

136. Hefnawy, M.M.; Al-Shehry, M.M.; Abounassif, A.; Mostafa, A.E. Enantioselective quantification of atenolol in mouse plasma by high-performance liquid chromatography using a chiral stationary phase: Application to a pharmacokinetic study. J. AOAC Int. 2013, 96, 976-980. [CrossRef] [PubMed]

137. Neves, D.V.; Vieira, C.P.; Coelho, E.B.; Marques, M.P.; Lanchote, V.L. Stereoselective analysis of nebivolol isomers in human plasma by high-performance liquid chromatography-tandem mass spectrometry: Application in pharmacokinetics. J. Chromatogr. B Anal. Technol. Biomed. Life Sci. 2013, 1, 47-52. [CrossRef] [PubMed]

138. Jiang, H.; Randlett, C.; Junga, H.; Jiang, X.; Ji, Q. Using supported liquid extraction together with cellobiohydrolase chiral stationary phases-based liquid chromatography with tandem mass spectrometry for enantioselective determination of acebutolol and its active metabolite diacetol in spiked human plasma. J. Chromatogr. B 2009, 877, 173-180. [CrossRef] [PubMed]

139. Oleksiak, J.S.; Walczak, M.; Bojarski, J.; Aboul-Enein, H.Y. Enatioselective high performance liquid chromatographic assay of acebutolol and its active metabolite diacetol in human serum. Chirality 1999, 11, 267-271. [CrossRef]

140. De Antunes, N.J.; Cavalli, R.C.; Marques, M.P.; Lanchote, V.L. Stereoselective determination of metoprolol and its metabolite $\alpha$-hydroxymetoprolol in plasma by LC-MS/MS: Application to pharmacokinetics during pregnancy. Chirality 2013, 25, 1-7. [CrossRef]

(C) 2019 by the authors. Licensee MDPI, Basel, Switzerland. This article is an open access article distributed under the terms and conditions of the Creative Commons Attribution (CC BY) license (http:/ / creativecommons.org/licenses/by/4.0/). 